\title{
Antioxidant and anti-inflammatory effects of curcumin against hepatorenal oxidative injury in an experimental sepsis model in rats
}

\author{
Gülay Yılmaz Savcun, M.D., ${ }^{1}$ Erkan Özkan, M.D., ${ }^{1}$ Ender Dulundu, M.D., ${ }^{2}$ Ümit Topaloğlu, M.D., ${ }^{1}$ \\ Ahmet Özer Şehirli, M.D., ${ }^{3}$ Olgu Enis Tok, M.D., ${ }^{4}$ Feriha Ercan, M.D., ${ }^{4}$ Göksel Şener, M.D. ${ }^{3}$ \\ ${ }^{1}$ Department of General Surgery, Haydarpasa Numune Training and Research Hospital, Istanbul \\ ${ }^{2}$ Department of General Surgery, Marmara University Faculty of Medicine, Istanbul \\ ${ }^{3}$ Department of Pharmacology, Marmara University Faculty of Pharmacy, Istanbul \\ ${ }^{4}$ Department of Histology and Embryology, Marmara University Faculty of Medicine, Istanbul
}

\begin{abstract}
BACKGROUND: To investigate the effects of curcumin, an antioxidant and anti-inflammatory agent, on free oxygen radicals and lipid peroxidation in an experimental sepsis model, as well as to determine the role of curcumin in preventing hepatorenal tissue damage caused by sepsis.

METHODS: The rats were randomly divided into three groups $(n=8)$ as follows: control group (group I); sepsis group (group 2); and sepsis + curcumin group (group 3). Sepsis was created using the cecal ligation and perforation (CLP) method. Curcumin was administered intraperitoneally $(200 \mathrm{mg} / \mathrm{kg})$ in two equal doses just after the perforation and at twelve hours post-perforation.

RESULTS: Serum TNF- $\alpha$ and IL- $\mid \beta$, and tissue MDA and MPO values were higher, whereas tissue GSH and Na+/K+-ATPase values were lower, in group 2 as compared to group I. These values in group 3 were the inverse of those in group 2 . As compared to group I, histopathological evaluation of group 2 showed damaged hepatocytes, glomeruli, and tubules, whereas the damage was significantly reduced in group 3 as compared to group 2.
\end{abstract}

CONCLUSION: The strong antioxidant and anti-inflammatory effects of curcumin against potential hepatorenal damage were shown using an experimental sepsis model in rats.

Key words: Curcumin; free oxygen radicals; sepsis.

\section{INTRODUCTION}

Sepsis is defined as an excessive and irregular systemic inflammatory reaction syndrome (SIRS) against infection. ${ }^{[1]}$ Bacterial lipopolysaccharide endotoxins activate macrophages, triggering the release of pro-inflammatory cytokines, and thus play a role in the development of systemic inflammatory response. One of the groups of mediators that are responsible for the

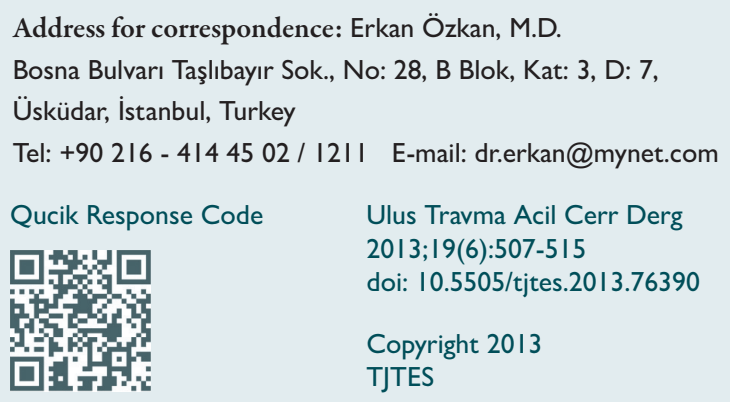

inflammatory response is free oxygen radicals. Free oxygen radicals disrupt cell membranes by causing lipid peroxidation, inhibit ATP synthesis in the mitochondria, and cause oxidative damage to DNA and proteins. ${ }^{[2]}$ Sepsis can also be defined as a harmful host response against infection. Despite aggressive surgical therapy, specific antibiotics, and other pharmacologic agents used, sepsis is the leading cause of mortality in intensive care units. ${ }^{[3]}$

Curcumin, which is known as the Indian spice turmeric, is used as a spice that gives a yellow color to food. Curcumin is obtained from the yellow powder of Curcuma longa (Zingiberaceae), a tropical plant. ${ }^{[4]}$ Curcumin has been widely used in Eastern populations, particularly as a traditional medicine in India and China, for the treatment of many diseases, including hepato-biliary, skin, rheumatoid, and gastrointestinal system diseases. ${ }^{[5]}$ The protective features of curcumin, first and foremost its antioxidant and anti-inflammatory effects, have been shown in clinical and experimental studies. ${ }^{[6-9]}$ 
In the present study, the antioxidant and anti-inflammatory effects of curcumin in reducing the damage caused by experimental sepsis in rats was investigated. The outcomes on clinical availability were discussed as well.

\section{MATERIALS AND METHODS}

The present experimental study was conducted in the Experimental Research and Animal Laboratory of Marmara University Faculty of Medicine after obtaining approval of the Local Ethics Committee. Both genders of Wistar albino rats, weighing between 200 and $250 \mathrm{~g}$, were included in the study. The rats were kept in a temperature-controlled $\left(22 \pm \mathrm{I}{ }^{\circ} \mathrm{C}\right)$ room with a $12: 12 \mathrm{~h}$ alternating light/dark cycle.

General anesthesia was induced with subcutaneous administration of ketamine $\mathrm{HCl}(50 \mathrm{mg} / \mathrm{kg})$ and xylazine $\mathrm{HCl}(15$ $\mathrm{mg} / \mathrm{kg})$.

The cecal ligation and perforation (CLP) model was used to induce sepsis. ${ }^{[10]}$ After shaving abdominal hair, the abdomen was entered through a $3-\mathrm{cm}$ incision. Following laparotomy, the cecum was isolated and filled with feces by milking stool back from the ascending colon. The cecum was then tightly ligated with 3-0 silk at its base, below the ileocecal valve; the anterior surface of the cecum was perforated twice with an 18-gauge needle, and the cecum was replaced into the abdomen after a small amount of feces was visualized. The abdomen was closed in two layers with 3-0 continuous silk sutures.

The animals were divided into 3 groups $(n=8)$ according to the antioxidant and anti-inflammatory goals, as below.

Group I (control group): The rats underwent anesthesia and surgery, but not CLP.

Group 2 (sepsis group): Sepsis was induced by the CLP method.

Group 3 (sepsis + curcumin group): Sepsis was induced by the CLP method. The rats were given curcumin $(200 \mathrm{mg} /$ $\mathrm{kg}$ ) via the intraperitoneal route in two equal doses just after surgery and at the post-operative 12 th hour.

All rats were sacrificed at the post-operative 24th hour. $A$ 2-cc blood sample was obtained from the vena cava. Tissue samples were obtained from the liver and the kidney. Plasma tumor necrosis factor-alpha (TNF- $\alpha$ ) and interleukin I-beta (IL-I $\beta$ ) levels were measured. Hepatic and renal tissue malondialdehyde (MDA) and glutathione (GSH) levels, as well as myeloperoxidase (MPO) and $\mathrm{Na}^{+} / \mathrm{K}^{+}$-ATPase activities, were determined. The tissue samples were examined under a light microscope for histopathological changes, including interstitial inflammation and peri-hepatic and -nephritic necroses.

\section{Biochemical Protocols}

\section{Serum analyses}

Plasma TNF- $\alpha$ and IL-I $\beta$ were quantified according to the manufacturer's instructions and guidelines using enzymelinked immunosorbent assay (ELISA) kits (Biosource International, Nivelles, Belgium). These kits were preferred because of the high degree of sensitivity, specificity, inter- and intra-assay precision, and the small amount of plasma sample required for conducting the assay.

\section{Malondialdehyde and glutathione assays}

Tissue samples from the liver and kidney were homogenized in ice-cold homogenization medium containing $150 \mathrm{mM} \mathrm{KCl}$ for determination of MDA and GSH levels. The MDA levels were assayed for products of lipid peroxidation. ${ }^{\left[{ }^{[1]}\right.}$ The results were expressed as nmol MDA/g tissue. GSH was determined by the spectrophotometric method using Ellman's reagent. [12] The results were expressed as $\mathrm{mmolGSH/g}$ tissue. Serum MDA and GSH levels were measured by the same methods.

\section{Myeloperoxidase activity}

Tissue-associated MPO activity was measured using a procedure similar to the procedure documented by Hillegas et al. ${ }^{[13]}$ Liver and kidney samples were homogenized in $50 \mathrm{mM}$ potassium phosphate buffer (PB; $\mathrm{pH} 6.0)$ and centrifuged at $4 \mathrm{l}, 400 \mathrm{~g}$ for $10 \mathrm{~min}$; the pellets were suspended in $50 \mathrm{mM} \mathrm{PB}$ containing $0.5 \%$ hexadecyltrimethylammonium bromide. After three freeze-thaw cycles, with sonication between cycles, the samples were centrifuged at 4I,400 g for $10 \mathrm{~min}$. Aliquots $(0.3 \mathrm{~mL})$ were added to $2.3 \mathrm{~mL}$ of reaction mixture containing $50 \mathrm{mM} \mathrm{PB}$, o-dianisidine, and $20 \mathrm{mM} \mathrm{H}_{2} \mathrm{O}_{2}$ solution. One unit of enzyme activity was defined as the amount of the MPO present that caused a change in absorbance measured at 460 $\mathrm{nm}$ for $3 \mathrm{~min}$. MPO activity was expressed as $\mathrm{U} / \mathrm{g}$ tissue.

\section{$\mathrm{Na}^{+} / \mathrm{K}^{+}$-ATPase activity}

Measurement of $\mathrm{Na}^{+} / \mathrm{K}^{+}$-ATPase activity is based on the measurement of inorganic phosphate that is formed from $3 \mathrm{mM}$ disodium adenosine triphosphate added to the medium during the incubation period. ${ }^{[14]}$ The medium was incubated in a $37^{\circ} \mathrm{C}$ water bath for 5 min with a mixture of $100 \mathrm{mM} \mathrm{NaCl}$, $5 \mathrm{mM} \mathrm{KCl}, 6 \mathrm{mM} \mathrm{MgCl}$, $0.1 \mathrm{mM}$ ethylenediaminetetraacetic acid, and $30 \mathrm{mM}$ Tris $\mathrm{HCl}(\mathrm{pH}$ 7.4). Following the pre-incubation period, $\mathrm{Na}_{2}$ ATP at a final concentration of $3 \mathrm{mM}$ was added to each tube and incubated at $37^{\circ} \mathrm{C}$ for $30 \mathrm{~min}$. After incubation, the tubes were placed in an ice bath and the reaction was stopped. Subsequently, the level of inorganic phosphate was determined using a spectrophotometer (Shimadzu, Japan) at an excitation wavelength of $690 \mathrm{~nm}$.

\section{Histopathological Examination}

After the tissue samples were fixed in a $10 \%$ formaldehyde solution, they were washed with tap water for at least $3 \mathrm{~h}$ or overnight. The tissue samples were gradually dehydrated by passage through increasing concentrations of alcohol (I $5 \mathrm{~min}$ 
Table I. Serum tumor necrosis factor-alpha and interleukin I-beta values of the control, sepsis, and sepsis + curcumin groups in the hepatorenal injury model induced by sepsis in rats

\begin{tabular}{lccc}
\hline & Control & Sepsis & Sepsis + Curcumin \\
\hline TNF- $\alpha(\mathrm{pg} / \mathrm{mL})$ & $8.48 \pm 1.25$ & $34.35 \pm 3.72^{\text {**** }}$ & $14.38 \pm 2.72^{+++}$ \\
$\mathrm{IL}-\mathrm{I} \beta(\mathrm{pg} / \mathrm{mL})$ & $9.79 \pm 1.45$ & $32.37 \pm 3.30^{\text {*o* }}$ & $17.19 \pm 2.66^{++}$ \\
\hline
\end{tabular}

TNF: Tumor necrosis factor; IL: Interleukin.

Data are presented as the mean \pm standard deviation.

$* * * \mathrm{p}<0.001$ as compared to the control group.

$++p<0.01 ;+++p<0.001$ as compared to the sepsis group.

with $70 \%$ alcohol, 15 min with $90 \%$ alcohol, 30 min with $96 \%$ alcohol, 30 min with $100 \%$ alcohol [twice], and 30 min with $100 \%$ toluene [twice]). Thereafter, the tissue samples were submerged in paraffin for I night at $60^{\circ} \mathrm{C}$ and embedded in paraffin blocks the next day. After the blocking process, 5-6 $\mu \mathrm{m}$-thick sections were obtained from the tissue samples and placed on slides. The sections were kept in toluene for $2 \mathrm{~h}$ to remove the paraffin. Subsequently, the sections were gradually hydrated by passage through decreasing concentrations of alcohol ( 2 min with $100 \%$ alcohol, 2 min with $90 \%$ alcohol, and 2 min with 70\% alcohol) and placed in distilled water. After staining with hematoxylin for 15 min, the sections were rinsed in tap water for 10 min for blueing. Following staining with eosin for 5 min and washing with distilled water, the sections were again gradually dehydrated by passage through increasing concentrations of alcohol ( 2 min with $70 \%$ alcohol, 2 min with $90 \%$ alcohol, 2 min with $96 \%$ alcohol, and 10 min with $100 \%$ alcohol). Subsequently, the sections were washed twice with toluene (the first wash lasted for $5 \mathrm{~min}$ and the second wash lasted for $10 \mathrm{~min}$ ), then covered with Entellan. The sections were examined under a light microscope (Olympus BHX5I; Tokyo, Japan).

\section{Statistical Analysis}

Statistical evaluation was performed with one-way analysis of variance (ANOVA) and Tukey's test. A p-value $<0.05$ was considered statistically significant. Comparison between the groups with respect to serum TNF- $\alpha$ and IL-I $\beta$, and hepatic and renal tissue GSH and MDA levels, as well as MPO and $\mathrm{Na}^{+} / \mathrm{K}^{+}$-ATPase activities were done using ANOVA; Tukey's test was used for pairwise comparisons.

\section{RESULTS}

\section{Biochemical $\mathrm{F}$ indings}

The serum TNF- $\alpha$ and IL-I $\beta$ levels were significantly higher

Table 2. Tissue glutathione, malondialdehyde, myeloperoxidase, and $\mathrm{Na}^{+} / \mathrm{K}^{+}-\mathrm{ATPase}$ values of the control, sepsis, and sepsis + curcumin groups in the hepatorenal injury model induced by sepsis in rats

\begin{tabular}{lccc}
\hline & Control & Sepsis & Sepsis + Curcumin \\
\hline GSH (mmol/g) & & & \\
$\quad$ Liver & $2.42 \pm 0.14$ & $1.70 \pm 0.17^{* *}$ & $2.30 \pm 0.11^{+}$ \\
Kidney & $1.66 \pm 0.16$ & $0.77 \pm 0.12^{* *}$ & $1.50 \pm 0.16^{+}$ \\
MDA (nmol/g) & & & \\
Liver & $19.55 \pm 2.16$ & $40.70 \pm 5.79^{* *}$ & $20.25 \pm 3.75^{++}$ \\
Kidney & $31.89 \pm 3.51$ & $66.62 \pm 6.65^{* * *}$ & $35.89 \pm 5.65^{++}$ \\
MPO (U/g) & & & \\
Liver & $12.68 \pm 1.20$ & $46.63 \pm 5.26^{* * *}$ & $24.43 \pm 4.43^{++}$ \\
Kidney & $9.13 \pm 1.32$ & $29.28 \pm 4.39^{* *}$ & $16.77 \pm 3.43^{+}$ \\
$\mathrm{Na}^{+} / \mathrm{K}^{+}$-ATPase (mmol/mg protein/h) & & & \\
Liver & $2.97 \pm 0.59$ & $1.10 \pm 0.18^{*}$ & $2.75 \pm 0.38^{+}$ \\
$\quad$ Kidney & $2.25 \pm 0.28$ & $1.12 \pm 0.15^{* *}$ & $2.20 \pm 0.20^{++}$ \\
\hline
\end{tabular}

GSH: Glutathione; MDA: Malondialdehyde; MPO: Myeloperoxidase. $*_{p}<0.05 ; * *<<0.01 ; * * * p<0.001$ as compared to the control group. $+p<0.05 ;++p<0.01 ;+++p<0.001$ as compared to the sepsis group. 
in group 2 compared to group I $(p<0.00 I)$. In contrast, the TNF- $\alpha$ and IL-I $\beta$ levels were significantly decreased in group 3 as compared to group 2 ( $p<0.001$ and $p<0.01$, respectively) and approached the levels of group I (Table I and Figure I).
Tissue GSH values were significantly lower in group 2 as compared to group I $(p<0.01)$. Tissue GSH values were significantly increased in group 3 as compared to group $2(p<0.05$; Table 2 and Figure 2). Hepatic and renal tissue MDA values

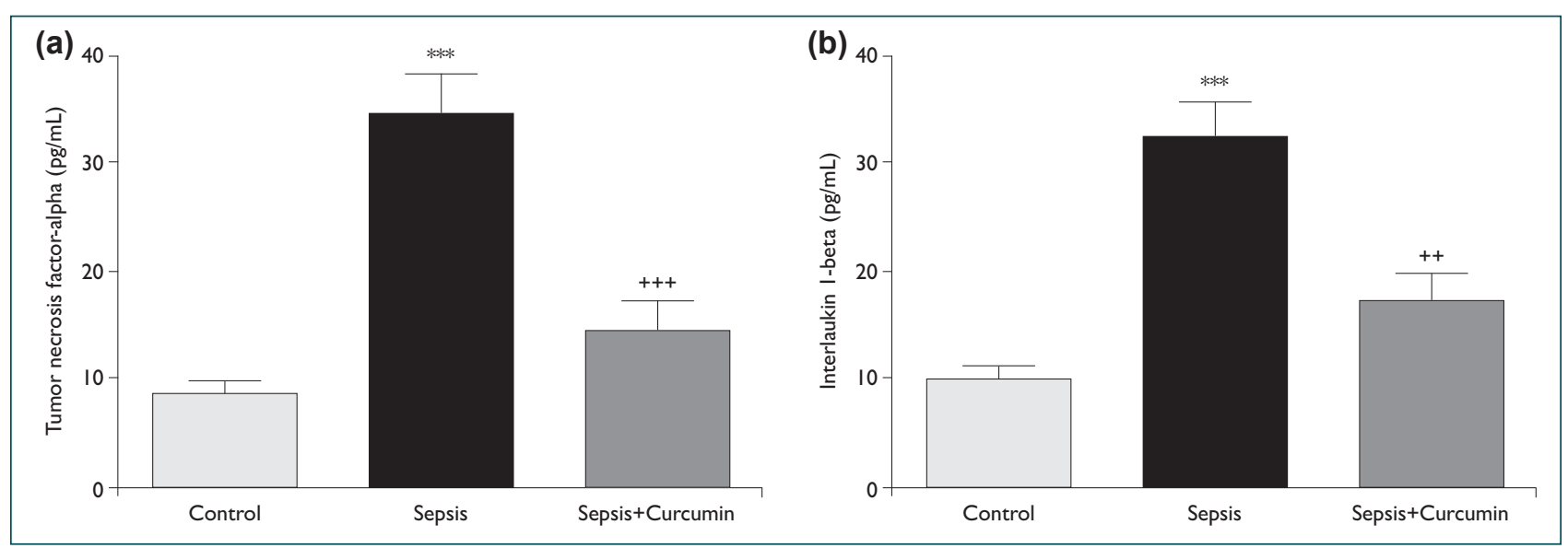

Figure 1. Serum (a) tumor necrosis factor-alpha (TNF- $\square$ ) and (b) interleukin 1-beta (IL-1 $\square$ ) values of the control, sepsis, and sepsis + curcumin groups in the hepatorenal injury model induced by sepsis in rats. ${ }^{* * *} p<0.001$ as compared to the control group; $++p<0.01$; $+++p<0.001$ as compared to the sepsis group.
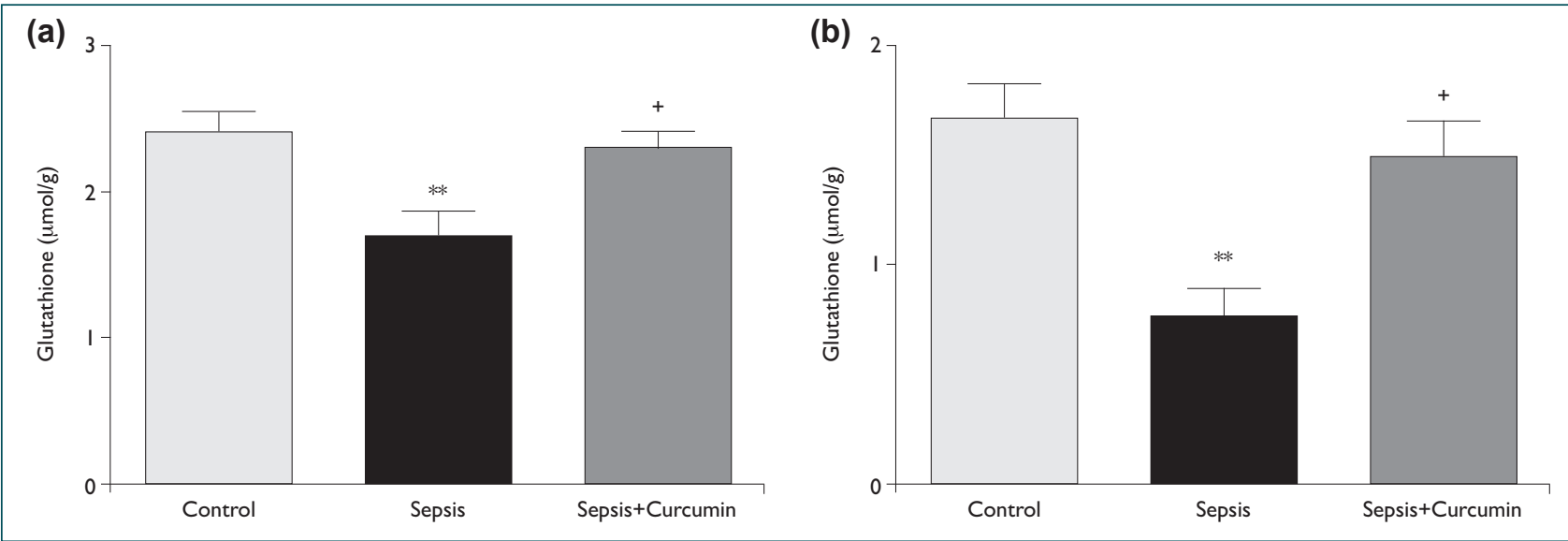

Figure 2. (a) Hepatic and (b) renal tissue glutathione (GSH) values of the control, sepsis, and sepsis + curcumin groups in the hepatorenal injury model induced by sepsis in rats. ${ }^{* *} p<0.01$ as compared to the control group; $+p<0.05$ as compared to the sepsis group.
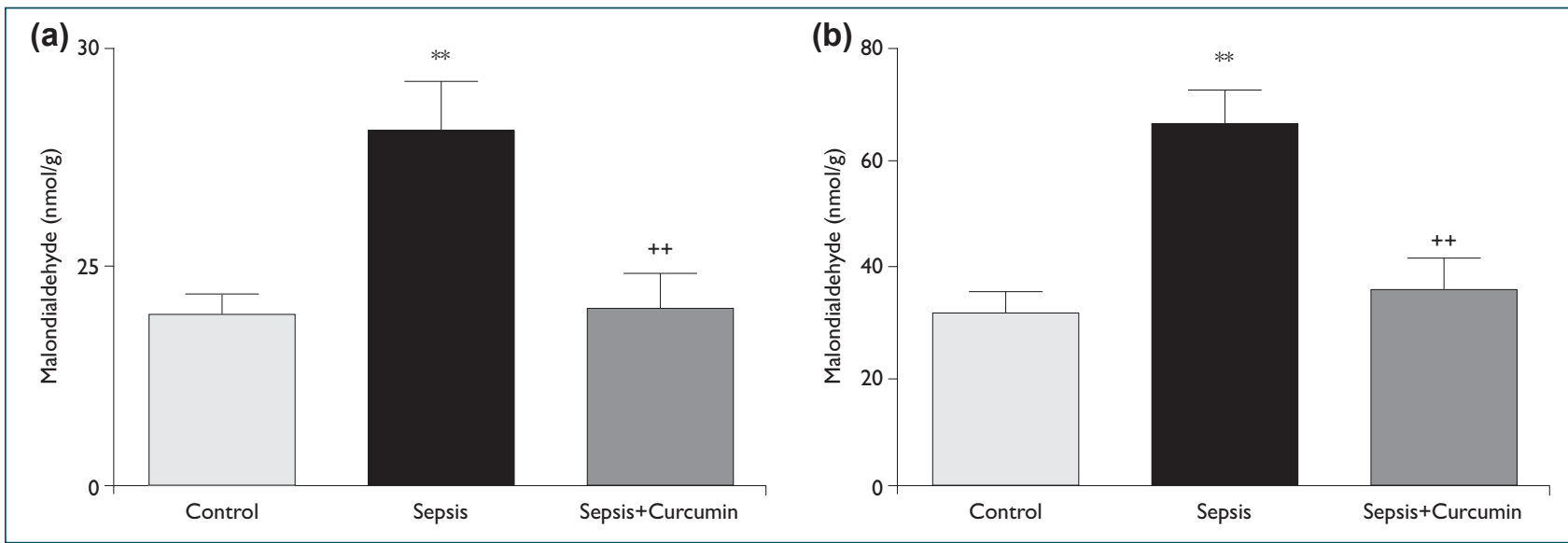

Figure 3. (a) Hepatic and (b) renal tissue malondialdehyde (MDA) values of the control, sepsis, and sepsis + curcumin groups in the hepatorenal injury model induced by sepsis in rats. ${ }^{* *} p<0.01$ as compared to the control group; $+p<0.05 ;++p<0.01$ as compared to the sepsis group. 

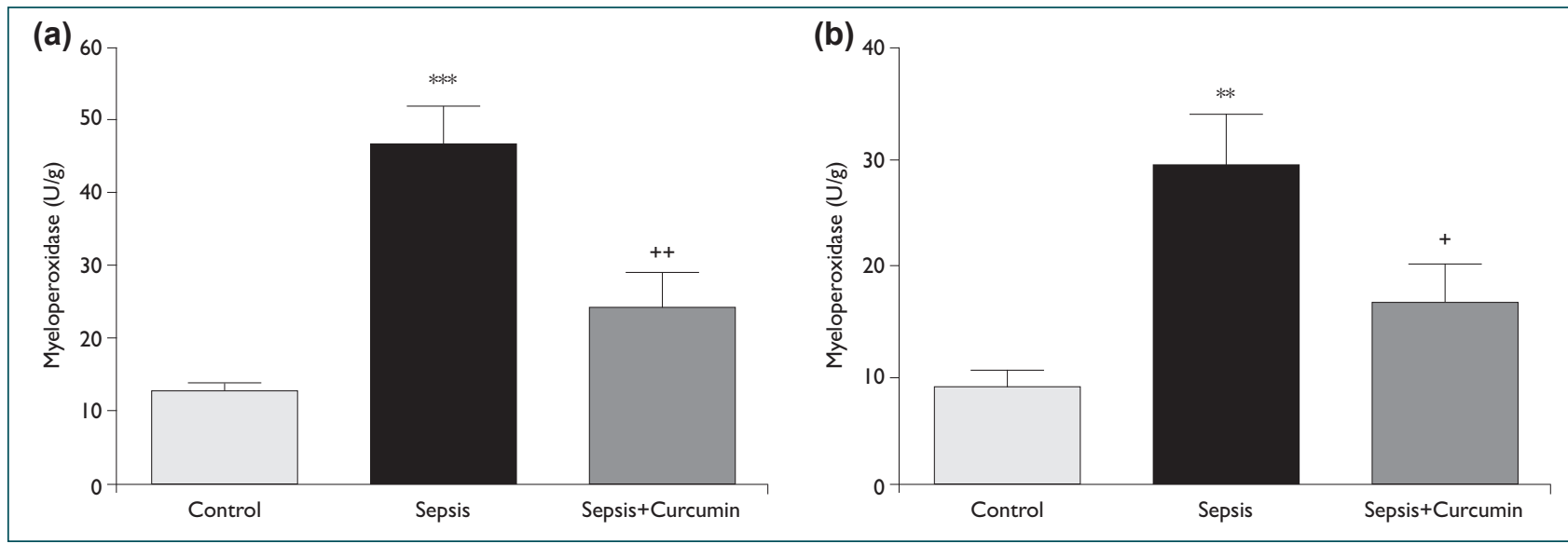

Figure 4. (a) Hepatic and (b) renal tissue myeloperoxidase (MPO) activities of the control, sepsis, and sepsis + curcumin groups in the hepatorenal injury model induced by sepsis in rats. ${ }^{* *} p<0.01 ;{ }^{* * *} p<0.001$ as compared to the control group; $+p<0.05 ;++p<0.01$ as compared to the sepsis group.
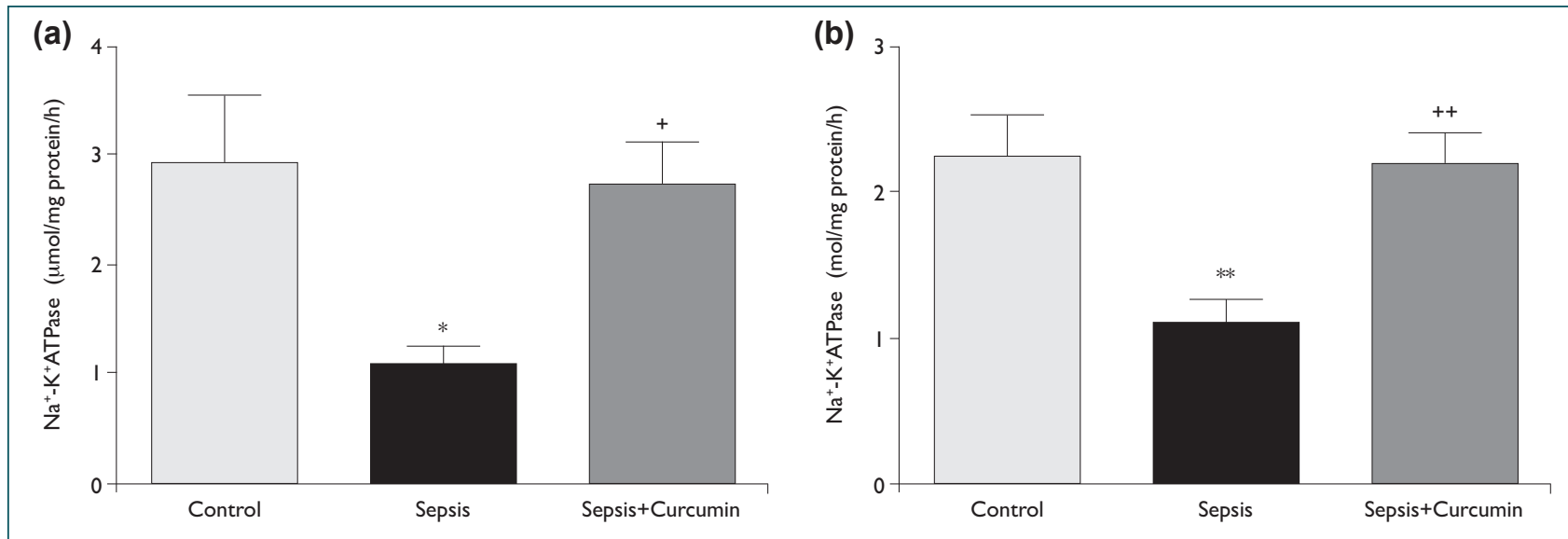

Figure 5. (a) Hepatic and (b) renal tissue $\mathrm{Na}^{+} / \mathrm{K}^{+}$-ATPase activities of the control, sepsis, and sepsis + curcumin groups in the hepatorenal injury model induced by sepsis in rats. ${ }^{*} p<0.05 ;{ }^{* *} p<0.01$ as compared to the control group; $+p<0.05 ;++p<0.01$ as compared to the sepsis group.

were significantly higher in group 2 as compared to group I $(p<0.01$ and $p<0.001$, respectively). Compared to group 2 , the tissue MDA values were significantly lower in group 3 $(\mathrm{p}<0.01$; Table 2 and Figure 3).

Hepatic and renal tissue MPO activities were significantly higher in group 2 as compared to group $I \quad(p<0.001$ and $\mathrm{p}<0.0$ I, respectively). Compared to group 2 , hepatic and renal tissue MPO activities were significantly decreased in group $3(p<0.01$ and $p<0.05$, respectively; Table 2 and Figure 4).

Hepatic and renal tissue $\mathrm{Na}^{+} / \mathrm{K}^{+}$-ATPase activities were significantly decreased in group 2 compared to group $I(p<0.05$ and $p<0.0$ I, respectively). Compared to group 2 , the tissue $\mathrm{Na}^{+} / \mathrm{K}^{+}$-ATPase activities were significantly increased in group $3(p<0.05$ and $p<0.0$ I, respectively; Table 2 and Figure 5).

\section{Histopathological Findings}

Hepatocytes and sinusoids with regular morphology were observed in the hepatic parenchyma of the control group (Fig- ure 6a). Severe sinusoidal dilation and congestion, damaged hepatocytes with numerous cytoplasmic vacuoles, and activated Kupffer cells were observed in the sepsis group (Figure $6 \mathrm{~b})$. Mild sinusoidal dilation and congestion, and hepatocytes, the majority of which showed normal morphology, were observed in the sepsis group treated with curcumin (Figure 6c).

The renal cortex of the control group (Figure 7a) had glomeruli and tubules with normal morphology. In the sepsis group (Figure 7b), damaged glomeruli with disappearance of Bowman's space, severe dilatation of the tubular lumen, and impaired tubular structure were observed. Glomerular and tubular damage were significantly reduced in the sepsis group treated with curcumin (Figure 7c).

\section{DISCUSSION}

Antioxidants are substances that prevent or delay oxidation of oxidizable substrates including proteins, lipids, carbohydrates, and DNA in living cells. If the precise balance between the level of free radicals and antioxidants cannot be 

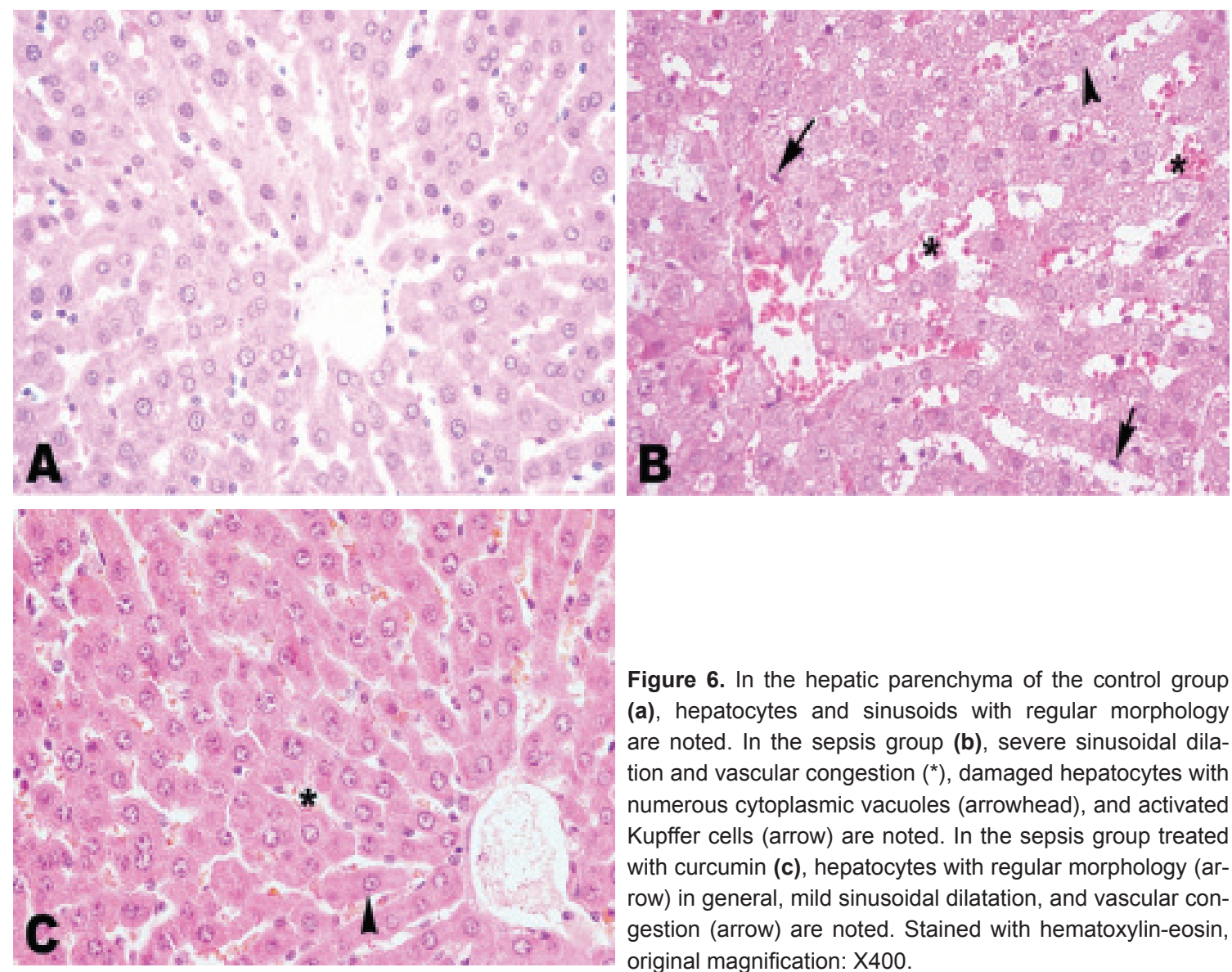

Figure 6. In the hepatic parenchyma of the control group (a), hepatocytes and sinusoids with regular morphology are noted. In the sepsis group (b), severe sinusoidal dilation and vascular congestion $\left({ }^{*}\right)$, damaged hepatocytes with numerous cytoplasmic vacuoles (arrowhead), and activated Kupffer cells (arrow) are noted. In the sepsis group treated with curcumin (c), hepatocytes with regular morphology (arrow) in general, mild sinusoidal dilatation, and vascular congestion (arrow) are noted. Stained with hematoxylin-eosin, original magnification: $\mathrm{X} 400$.
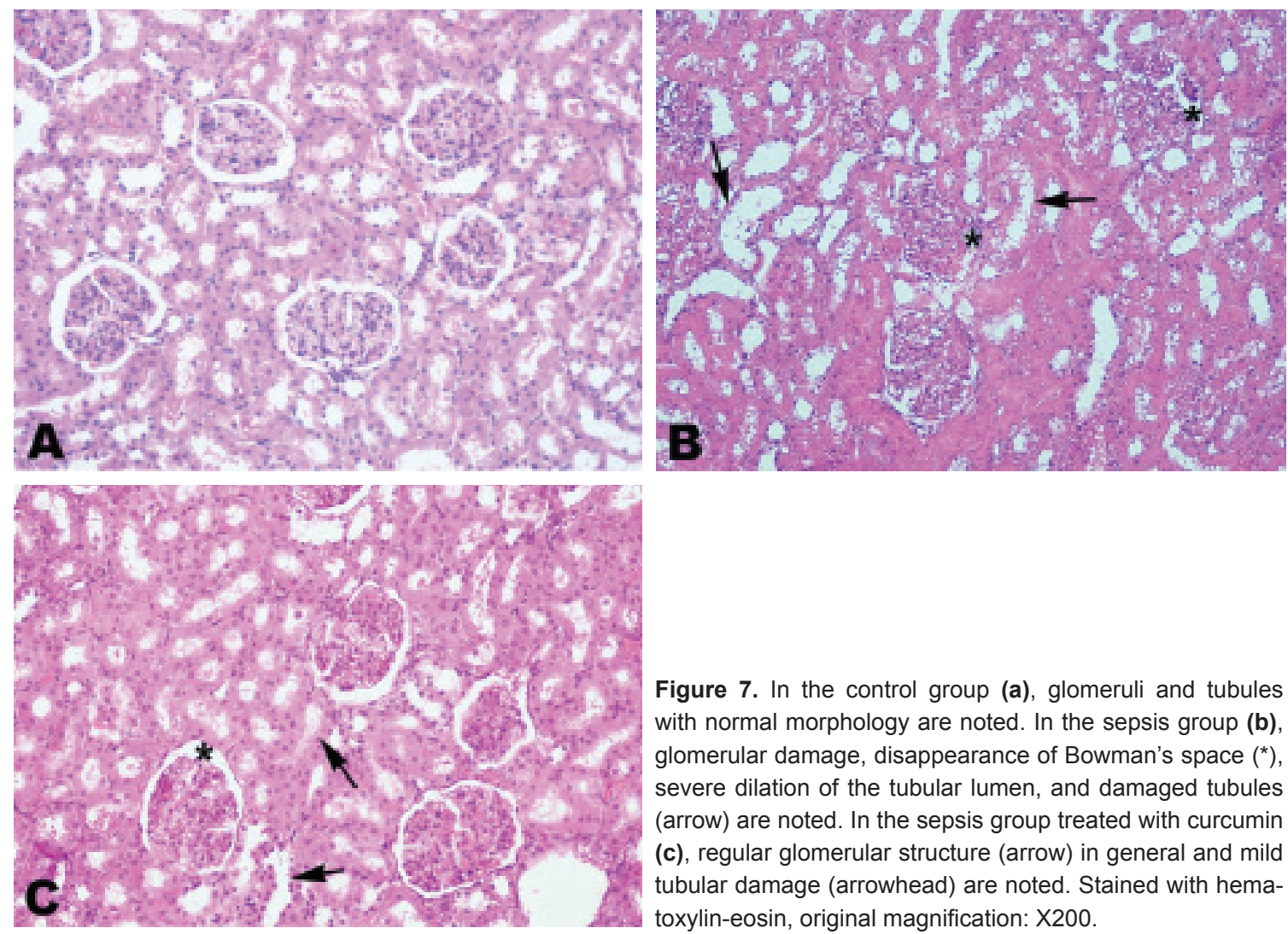

Figure 7. In the control group (a), glomeruli and tubules with normal morphology are noted. In the sepsis group (b), glomerular damage, disappearance of Bowman's space $\left(^{*}\right)$, severe dilation of the tubular lumen, and damaged tubules (arrow) are noted. In the sepsis group treated with curcumin (c), regular glomerular structure (arrow) in general and mild tubular damage (arrowhead) are noted. Stained with hematoxylin-eosin, original magnification: X200. 
protected, various pathologic changes that may lead to cell damage occur. ${ }^{[15]}$

Although the underlying physiopathological mechanisms are quite complex in the septic response, advances in molecular biology have allowed understanding of the majority of the pathologic events in sepsis. Free oxygen radicals that are produced during sepsis cause tissue damage by causing damage to DNA, denaturing cellular proteins, and causing peroxidation of membrane lipids. ${ }^{[16]}$

As the physiopathological mechanisms of sepsis have been elucidated, studies on the mechanism of action of mediators and cytokines that play a role in the process, as well as on the changes they cause in the body, have continued. As the understanding of the role of antioxidants increases, it is thought that antioxidant agents that are used to neutralize the effects of free oxygen radicals may have a role in the treatment of sepsis. ${ }^{[17]}$

Curcumin, which is the active ingredient of turmeric (Curcuma longa) and has been used in the Indian medical tradition nearly for 4000 years, is a natural exogenous antioxidant. Curcumin inhibits lipid peroxidation and oxidative DNA damage, and reduces the release of arachidonic acid through lipoxygenase and cyclooxygenase inhibition. Moreover, curcumin shows an anti-inflammatory effect by inhibiting NFKB activation. Curcumin facilitates excretion of many oxygen radicals, particularly superoxide anion, nitrogen dioxide, and hydrogen radicals. ${ }^{[18,19]}$

Although it is difficult to create a supportive treatment environment similar to that applied in intensive care units in animal models, experimental models are of great importance in understanding the physiopathology of septic shock and finding new therapeutic approaches prior to clinical trials. The CLP model used in the present study creates a model similar to the clinical features of septic shock and resembles human sepsis, as the CLP model displays hypodynamic and hypometabolic phases following the hypermetabolic phase. ${ }^{[20]}$ Therefore, it is the closest model to the clinical situation among sepsis models in rats. Unlike the other models (models created by injection of lipopolysaccharides or by intravenous or intraperitoneal infusion of live bacteria), the CLP model has advantages such as providing continuous intraperitoneal contamination without impairing the intestinal integrity, leading to a representation of septic shock in which numerous types of microorganisms are observed (polymicrobial), thus creating a model similar to clinical septic shock (perforated appendicitis, diverticulitis, and colon perforation) ${ }^{[21]}$

Pathologic changes may occur in many organs in patients with sepsis. The most commonly affected organs are the lungs, liver, kidneys, heart, and intestines. ${ }^{[2]}$ These pathologic changes include changes caused by bacterial invasion, direct effect of bacterial toxins and enzymes, mediator-mediated effects, im- paired perfusion, and disseminated intravascular coagulation.

In the present study, hepatic and renal pathologic changes caused by oxidative damage occurred during experimentallyinduced sepsis in rats were biochemically and histologically evaluated. The effects of curcumin, of which strong antioxidant and anti-inflammatory effects are known, against this damage were also investigated.

The septic response of the organism comprises complex relationships between microbial signalling molecules, leukocytes, humoral mediators, and the vascular endothelium. Inflammatory cytokines strengthen and diversify the host response. TNF- $\alpha$ stimulates leukocytes and vascular endothelial cells to release other cytokines, express cell surface adhesion molecules and increase arachidonic acid turnover. Serum TNF- $\alpha$ levels are elevated during severe sepsis or septic shock. ${ }^{[23]}$ Although TNF- $\alpha$ is the main mediator, it is only one of numerous cytokines that are involved in the septic process. For example, IL-I $\beta$, which has many TNF- $\alpha$ activities, plays a gradually increasing role in the progression of sepsis. TNF- $\alpha$, IL-I $\beta$, IL-8, and other mediators show complementary effects with each other. In animal experiments, neutralizing one or several of these components can prevent the septic response. ${ }^{[24,25]}$ In the present study, serum TNF- $\alpha$ and IL-I $\beta$ levels were higher in the sepsis group as compared to the control group $(p<0.001)$. This increase was significantly decreased in the sepsis group treated with curcumin $(p<0.00 \mathrm{I}$ and $p<0.0 \mathrm{I}$, respectively). Curcumin decreased TNF- $\alpha$ and IL-I $\beta$ levels by preventing inflammation.

There are several defense mechanisms against the toxic effects of free oxygen radicals. GSH is a natural antioxidant defense system. GSH is found in high concentrations in all cells and in epithelial surface fluid. GSH shows a protective effect by neutralizing free radicals and reactive oxygen intermediates. Furthermore, GSH also inactivates endogenous compounds such as prostaglandins and leukotrienes. ${ }^{[2,27]}$

Ahmida ${ }^{[28]}$ demonstrated an elevation in GSH levels with curcumin therapy given against renal damage induced by vancomycin in rats. Similarly, the antioxidant effect of curcumin has also been shown in a gentamicin-induced renal injury model ${ }^{[29]}$ and in aflatoxin- and paracetamol-induced hepatic injury models, ${ }^{[30,31]}$ and significant elevations were observed in tissue GSH levels. In the present study, hepatic and renal tissue GSH levels were lower in the sepsis group as compared to the control group $(p<0.0 I)$. However, hepatic and renal tissue GSH levels were significantly increased in the sepsis group treated with curcumin as compared to the sepsis group $(p<0.05)$.

MDA is one of the highly reactive metabolic products that are produced as the result of a series of reactions due to lipid peroxidation caused by the effect of free oxygen radicals on the tissues. ${ }^{[32]}$ The levels of intracellular enzymes such 
as MDA, which are lipid peroxidation products, are elevated in sepsis and worsen tissue damage by denaturing proteins. MDA measurement is used as an indicator of lipid peroxidation. ${ }^{[33]}$ In an acetaminophen-induced renal injury model in rats, Cekmen et al. ${ }^{[34]}$ showed that renal tissue MDA levels were decreased with curcumin. Moreover, tissue MDA levels were also decreased with curcumin in a renal ischemia/ reperfusion model ${ }^{[35]}$ and in a methotrexate-induced hepatic injury model. ${ }^{[6]}$ In the present study, hepatic and renal tissue MDA levels were found to be significantly higher in the sepsis group as compared to the control group $(p<0.01$ and $\mathrm{p}<0.00$ I, respectively). It was observed that MDA levels were significantly decreased in the sepsis group treated with curcumin as compared to the sepsis group $(p<0.01)$.

Free oxygen radicals cause tissue damage directly and also lead to the accumulation of polymorphonuclear leukocytes (PMNLs) in damaged tissue. Neutrophils and monocytes express MPO. PMNLs, which migrate to the tissues after being activated, release enzymes such as MPO. Oxidation of these enzymes causes formation of toxic agents that can affect the microorganism in various ways and leads to cell death. This enzyme enhances both tissue damage and formation of radicals. ${ }^{[36]}$ Tissue MPO levels have been reported to be decreased with curcumin therapy in ischemia/reperfusionand amiodarone-induced pulmonary fibrosis models. ${ }^{[37,38]}$ In the present study, hepatic and renal tissue MPO levels were significantly higher in the sepsis group as compared to the control group $(p<0.001$ and $p<0.01$, respectively). MPO levels were significantly decreased in the sepsis group treated with curcumin as compared to the sepsis group $(p<0.01$ and $\mathrm{p}<0.05$, respectively).

The $\mathrm{Na}^{+} / \mathrm{K}^{+}$-ATPase enzyme helps to preserve cellular membrane potential and osmotic gradient and is necessary for cellular functions. The negative effects of free radicals on $\mathrm{Na}^{+} / \mathrm{K}^{+}$-ATPase enzyme are one of the most emphasized mechanisms that are considered to be responsible for impaired enzyme activity. It is known that transport proteins are quite susceptible to changes in reactive oxygen species. During sepsis, oxidative stress causes lipid peroxidation in erythrocyte membranes and alterations in membrane lipid composition. As a result of these alterations in erythrocyte membranes, $\mathrm{Na}^{+} / \mathrm{K}^{+}$-ATPase activity and membrane viscosity are decreased. ${ }^{[39-41]}$ In the present study, hepatic and renal tissue $\mathrm{Na}^{+} / \mathrm{K}^{+}$-ATPase activities were lower in the sepsis group as compared to the control group $(p<0.05$ and $p<0.01$, respectively). However, hepatic and renal tissue $\mathrm{Na}^{+} / \mathrm{K}^{+}$-ATPase activities were significantly higher in the sepsis group treated with curcumin as compared to the sepsis group $(p<0.05$ and $\mathrm{p}<0.0$ I, respectively).

In conclusion, the present study showed strong antioxidant and anti-inflammatory effects of curcumin against the tissue damage likely caused by free oxygen radicals and lipid peroxidation induced by experimental sepsis created in rats. We are of the opinion that further studies on this issue will show the benefits of curcumin in reducing or preventing the toxic effects of sepsis.

\section{Conflict of interest: None declared.}

\section{REFERENCES}

1. American College of Chest Physicians/Society of Critical Care Medicine Consensus Conference: definitions for sepsis and organ failure and guidelines for the use of innovative therapies in sepsis. Crit Care Med 1992;20:864-74. [CrossRef ]

2. Bostanoglu A, Bostanoglu S, Erverdi N, Hamamc1 O, Özgen G, Dursun A, Korkmaz A. The role of oxygen free radicals in an experimental sepsis model. The Turkish Journal of Gastroenterology 1999;10:427-31.

3. Angus DC, Linde-Zwirble WT, Lidicker J, Clermont G, Carcillo J, Pinsky MR. Epidemiology of severe sepsis in the United States: analysis of incidence, outcome, and associated costs of care. Crit Care Med 2001;29:1303-10. [CrossRef ]

4. Aggarwal BB, Sundaram C, Malani N, Ichikawa H. Curcumin: the Indian solid gold. Adv Exp Med Biol 2007;595:1-75. [CrossRef ]

5. Zhou H, Beevers CS, Huang S. The targets of curcumin. Curr Drug Targets 2011;12:332-47. [CrossRef ]

6. Hemeida RA, Mohafez OM. Curcumin attenuates methotraxate-induced hepatic oxidative damage in rats. J Egypt Natl Canc Inst 2008;20:141-8.

7. Menon VP, Sudheer AR. Antioxidant and anti-inflammatory properties of curcumin. Adv Exp Med Biol 2007;595:105-25. [CrossRef]

8. Jacob A, Wu R, Zhou M, Wang P. Mechanism of the Anti-inflammatory Effect of Curcumin: PPAR-gamma Activation. PPAR Res 2007;2007:89369. [CrossRef ]

9. Kumar P, Padi SS, Naidu PS, Kumar A. Possible neuroprotective mechanisms of curcumin in attenuating 3-nitropropionic acid-induced neurotoxicity. Methods Find Exp Clin Pharmacol 2007;29:19-25. [CrossRef]

10. Otero-Antón E, González-Quintela A, López-Soto A, López-Ben S, Llovo J, Pérez LF. Cecal ligation and puncture as a model of sepsis in the rat: influence of the puncture size on mortality, bacteremia, endotoxemia and tumor necrosis factor alpha levels. Eur Surg Res 2001;33:77-9.

11. Buege JA, Aust SD. Microsomal lipid peroxidation. Methods Enzymol 1978;52:302-10. [CrossRef ]

12. Beutler E. Glutathione in red blood cell metabolism. A manual of biochemical methods. New York: Grune \&Stratton; 1975. p. 112-4.

13. Hillegass LM, Griswold DE, Brickson B, Albrightson-Winslow C. Assessment of myeloperoxidase activity in whole rat kidney. J Pharmacol Methods 1990;24:285-95. [CrossRef]

14. Reading HW, Isbir T. The role of cation-activated ATPases in transmitter release from the rat iris. QJ Exp Physiol Cogn Med Sci 1980;65:105-16.

15. Halliwell B, Whiteman M. Measuring reactive species and oxidative damage in vivo and in cell culture: how should you do it and what do the results mean? Br J Pharmacol 2004;142:231-55. [CrossRef]

16. Bone RC. Gram-negative sepsis. Background, clinical features, and intervention. Chest 1991;100:802-8. [CrossRef]

17. Del Sorbo L, Zhang H. Is there a place for $\mathrm{N}$-acetylcysteine in the treatment of septic shock? Crit Care 2004;8:93-5. [CrossRef]

18. Epstein J, Sanderson IR, Macdonald TT. Curcumin as a therapeutic agent: the evidence from in vitro, animal and human studies. Br J Nutr 2010;103:1545-57. [CrossRef]

19. Thiyagarajan M, Sharma SS. Neuroprotective effect of curcumin in middle cerebral artery occlusion induced focal cerebral ischemia in rats. Life Sci 2004;74:969-85. [CrossRef]

20. Rittirsch D, Hoesel LM, Ward PA. The disconnect between animal models of sepsis and human sepsis. J Leukoc Biol 2007;81:137-43. [CrossRef ]

21. İskit AB. Sepsiste deneysel modeller. Yoğun Bakım Dergisi 2005;5:1336. 
22. Wheeler AP, Bernard GR. Treating patients with severe sepsis. N Engl J Med 1999;340:207-14. [CrossRef]

23. Reiter RJ, Tan DX, Manchester LC, Qi W. Biochemical reactivity of melatonin with reactive oxygen and nitrogen species: a review of the evidence. Cell Biochem Biophys 2001;34:237-56. [CrossRef ]

24. Landmann R, Zimmerli W, Sansano S, Link S, Hahn A, Glauser MP, et al. Increased circulating soluble CD14 is associated with high mortality in gram-negative septic shock. J Infect Dis 1995;171:639-44. [CrossRef ]

25. Wang H, Bloom O, Zhang M, Vishnubhakat JM, Ombrellino M, Che J, et al. HMG-1 as a late mediator of endotoxin lethality in mice. Science 1999;285:248-51. [CrossRef]

26. Çetiner M, Şener G, Demiralp. Metotreksat tedavisine bağlı ince barsakta oluşan oksidatif doku hasarında L-Karnitinin koruyucu etkisi. Turkish Journal of Haematology 2004;21 Supp. 3:50.

27. Ozkan E, Akyüz C, Sehirli AO, Topaloğlu U, Ercan F, Sener G. Montelukast, a selective cysteinyl leukotriene receptor 1 antagonist, reduces cerulein-induced pancreatic injury in rats. Pancreas 2010;39:1041-6.

28. Ahmida MH. Protective role of curcumin in nephrotoxic oxidative damage induced by vancomycin in rats. Exp Toxicol Pathol 2012;64:149-53.

29. Farombi EO, Ekor M. Curcumin attenuates gentamicin-induced renal oxidative damage in rats. Food Chem Toxicol 2006;44:1443-8. [CrossRef]

30. El-Agamy DS. Comparative effects of curcumin and resveratrol on aflatoxin B(1)-induced liver injury in rats. Arch Toxicol 2010;84:389-96.

31. Girish C, Koner BC, Jayanthi S, Ramachandra Rao K, Rajesh B, Pradhan SC. Hepatoprotective activity of picroliv, curcumin and ellagic acid compared to silymarin on paracetamol induced liver toxicity in mice. Fundam Clin Pharmacol 2009;23:735-45. [CrossRef]

32. Kaçmaz A, Polat A, User Y, Tilki M, Ozkan S, Sener G. Octreotide improves reperfusion-induced oxidative injury in acute abdominal hypertension in rats. J Gastrointest Surg 2004;8:113-9. [CrossRef ]
33. Akyol Ö, İşçi N, Temel İ. The relationship between plasma and erythrocyte antioxidant enzymes and lipid peroxidation in patients with rheumatoid arthritis. Joint Bone Spine 2001;68:311-7. [CrossRef ]

34. Cekmen M, Ilbey YO, Ozbek E, Simsek A, Somay A, Ersoz C. Curcumin prevents oxidative renal damage induced by acetaminophen in rats. Food Chem Toxicol 2009;47:1480-4. [CrossRef ]

35. Bayrak O, Uz E, Bayrak R, Turgut F, Atmaca AF, Sahin S, et al. Curcumin protects against ischemia/reperfusion injury in rat kidneys. World J Urol 2008;26:285-91. [CrossRef]

36. Pascual JL, Khwaja KA, Ferri LE, Giannias B, Evans DC, Razek T, et al. Hypertonic saline resuscitation attenuates neutrophil lung sequestration and transmigration by diminishing leukocyte-endothelial interactions in a two-hit model of hemorrhagic shock and infection. J Trauma 2003;54:121-32. [CrossRef ]

37. Karatepe O, Gulcicek OB, Ugurlucan M, Adas G, Battal M, Kemik A, et al. Curcumin nutrition for the prevention of mesenteric ischemiareperfusion injury: an experimental rodent model. Transplant Proc 2009;41:3611-6. [CrossRef ]

38. Punithavathi D, Venkatesan N, Babu M. Protective effects of curcumin against amiodarone-induced pulmonary fibrosis in rats. $\mathrm{Br} \mathrm{J}$ Pharmacol 2003;139:1342-50. [CrossRef ]

39. Ozkan E, Yardimci S, Dulundu E, Topaloğlu U, Sehirli O, Ercan F, et al. Protective potential of montelukast against hepatic ischemia/reperfusion injury in rats. J Surg Res 2010;159:588-94. [CrossRef ]

40. Konukoglu D, Kemerli GD, Sabuncu T, Hatemi H. Relation of erythrocyte $\mathrm{Na}+\mathrm{K}+$ ATPase activity and cholesterol and oxidative stress in patients with type 2 diabetes mellitus. Clin Invest Med 2003;26:279-84.

41. Mahmmoud YA. Curcumin modulation of $\mathrm{Na}, \mathrm{K}-\mathrm{ATP}$ ase: phosphoenzyme accumulation, decreased $\mathrm{K}+$ occlusion, and inhibition of hydrolytic activity. Br J Pharmacol 2005;145:236-45. [CrossRef ]

\title{
DENEYSEL ÇALIŞMA - ÖZET
}

\section{Sıçanlarda deneysel sepsis modelinde oluşan hepatorenal oksidatif hasara karşı curcuminin antioksidan ve antienflamatuvar etkisi \\ Dr. Gülay Yılmaz Savcun, ${ }^{1}$ Dr. Erkan Özkan, ${ }^{1}$ Dr. Ender Dulundu, ${ }^{2}$ Dr. Ümit Topaloğlu, ${ }^{1}$ Dr. Ahmet Özer Şehirli, ${ }^{3}$ Dr. Olgu Enis Tok, ${ }^{4}$ Dr. Feriha Ercan, ${ }^{4}$ Dr. Göksel Şener ${ }^{3}$}

\author{
${ }^{1}$ Haydarpaşa Numune Eğitim ve Araştırma Hastanesi, Genel Cerrahi Kliniği, İstanbul \\ ${ }^{2}$ Marmara Üniversitesi Tıp Fakültesi, Genel Cerrahi Anabilim Dalı, İstanbul \\ ${ }^{3}$ Marmara Üniversitesi Eczacılık Fakültesi, Farmakoloji Anabilim Dalı, İstanbul \\ ${ }^{4}$ Marmara Üniversitesi Tıp Fakültesi, Histoloji ve Embriyoloji Anabilim Dalı, İstanbul
}

AMAÇ: Deneysel sepsis modelinde antioksidan ve antienflamatuvar bir ajan olan curcuminin serbest oksijen radikalleri, lipit peroksidasyonu üzerine olan etkileri ve sepsisin neden olduğu karaciğer ve böbrek doku hasarını önlemedeki rolü araştırıldı.

GEREÇ VE YÖNTEM: Sıçanlar rastgele sekizerli üç gruba ayrıldı. Sıçanlarda sepsis çekum ligasyon perforasyon (ÇLP) yöntemiyle oluşturuldu. Gruplar, kontrol grubu (Grup I), sepsis grubu (Grup 2), sepsis + curcumin grubu (Grup 3) şeklinde oluşturuldu. Curcumin intraperitoneal (i.p) yoldan (200 mg/kg) iki eşit dozda çekum perforasyonundan sonra 0. ve I2. saatlerde verildi.

BULGULAR: Gruplar karşılaştıııldığında grup 2'de grup I'e göre serum TNF- $\alpha$, IL-Iß değerleri, doku MDA, MPO değerleri yüksek, doku GSH, $\mathrm{Na}^{+}-\mathrm{K}^{+}$ATP az değerleri ise düşük bulundu. Grup 3'te ise grup 2'ye göre bu değerler tersine değiştiği belirlendi. Grup 2'de grup I'e göre histopatolojik değerlendirmede hasarlı hepatosit, glomerulus ve tubulus yapısı görülürken grup 3'te grup 2'ye göre bu hasarların belirgin şekilde azaldığı görüldü.

TARTIŞMA: Sıçanlarda deneysel sepsis modeli sonucu karaciğer ve böbrek dokusunda oluşabilecek doku hasarına karşı curcuminin güçlü antioksidan ve antienflamatuvar etkisi gösterildi.

Anahtar sözcükler: Curcumin; serbest oksijen radikalleri; sepsis.

Ulus Travma Acil Cerr Derg 2013;19(6):507-5।5 doi: 10.5505/tites.2013.76390 